J. Lake Sci. (湖泊科学), 2013, 25(3):378-385

http: //www. jlakes.org. E-mail: jlakes@niglas.ac.cn

(C) 2013 by Journal of Lake Sciences

\title{
三峡水库长江干流及其支流枯水期浮游植物多样性与水质"
}

\author{
朱爱民,胡菊香, 李嗣新, 周连凤, 梁友光
}

(水利部、中国科学院水工程生态研究所,水利部水工程生态效应与生态修复重点实验室,武汉 430079)

\begin{abstract}
摘 要: 2010 年 4 月对长江干流和 26 条支流未淹没区与回水区的浮游植物进行调查. 结果表明, 硅藻、绿藻和蓝藻共占 浮游植物种类的 $93.33 \% \sim 93.88 \%$. 干流优势种类有 1 门 1 种、未淹没区有 3 门 6 种、回水区有 5 门 6 种, 出现率分别为 $15.38 \%$ 、 $9.23 \%$ 和 $25.00 \%$. 回水区现存量平均值最高、未淹没区其次、干流最低. 现存量组成在干流、未淹没区和回水区 之间有差异, 绿藻所占比例干流最高, 硅藻所占比例未淹没区最高, 隐藻、蓝藻和甲藻所占比例均在回水区最高. ShannonWiener 多样性指数 $\left(H^{\prime}\right)$ 和 Pielou 均匀性指数 $(J)$, 未淹没区最高、干流次之、回水区最低. 17 条支流回水区 $H^{\prime}$ 和 8 条支流 回水区 $J$ 均低于未淹没区. 水质评价显示, 轻或无污染断面 (采样点) 的比例, 干流为 $76.92 \%$, 未淹没区为 $84.62 \%$, 回水 区为 $47.06 \% .19$ 条 $(73.08 \%)$ 支流回水区出现中污染或重污染,7 条( $26.92 \%)$ 支流未淹没区出现中污染或重污染.三峡 工程蓄水对回水区浮游植物与水质影响比长江干流更大.
\end{abstract}

关键词: 三峡水库;长江干流; 支流;浮游植物;多样性;水质

\section{Phytoplankton diversity and water quality in the main stream and tributaries of Three Gor- ges Reservoir region of Yangtze River during dry season}

\author{
ZHU Aimin, HU Juxiang, LI Sixin, ZHOU Lianfeng \& LIANG Youguang \\ (Key Laboratory of Ecological Impacts of Hydraulic-Projects and Restoration of Aquatic Ecosystem of Ministry of Water Re- \\ sources, Institute of Hydroecology, Ministry of Water Resources and Chinese Academy of Sciences, Wuhan 430079, P. R. \\ China)
}

Abstract: A survey on phytoplankton was carried out along the main stream of the Yangtze River and inundated and backwater areas of 26 tributaries in April, 2010. Species of diatoms, green algae and cyanobacteria accounted for $93.33 \%-93.88 \%$ of the total phytoplankton. Dominant species in the main stream, inundated area, and backwater area were 1 species in 1 phylum, six species in 3 phyla and 6 species in 5 phyla, respectively. The occurrence rates of dominant species in the main stream, inundated area, and backwater area were $15.38 \%, 9.23 \%$ and $25.00 \%$, respectively. The average value of phytoplankton standing stock was the highest in backwater area, followed by inundated area and the lowest in the main stream. Compositions of phytoplankton standing stock were different among the main stream, inundated area and backwater area. The proportions of green algae and diatom were the highest in the main stream and inundated area, while the proportions of cryptophyta, cyanophyta and pyrrophyta were all the highest in backwater area. Shannon-Wiener diversity indexes and Pielou evenness indexes were the highest in inundated area, followed by the main stream, and the lowest in backwater area. Shannon-Wiener diversity indexes of backwater area of 17 tributaries and Pielou evenness of backwater area of 8 tributaries were both lower than those inundated area. Water quality assessment indicated that the proportions of slightly polluted or not polluted monitoring sections in the main stream, inundated area and backwater area were $76.92 \%, 84.62 \%$ and $47.06 \%$, respectively. Moderate polluted or seriously polluted were found in backwater area of 19 tributaries $(73.08 \%)$ and inundated area of 7 tributaries $(26.92 \%)$. The influence of the Three Gorges Dam Project on phytoplankton and water quality in backwater area is greater than that in the main stream of Yangtze River.

Keywords: Three Gorges Reservoir; main stream of Yangtze River; tributary; phytoplankton; diversity; water quality

* 国家水体污染控制与治理科技重大专项项目 (2009ZX07528-003)、科技部中德合作项目 (2008DFA31550)、湖北省 自然科学基金重点项目 (2008CDA092) 和国家自然科学基金项目 (51209150,51149005) 联合资助. 2012 - $04-08$ 收稿;2012-10-24 收修改稿. 朱爱民,男,1963 年生,研究员;E-mail:zham@ mail. ihe. ac. cn. 
三峡水库长江沿岸主要的一级支流有 40 条, 其中流域面积为 $1000 \mathrm{~km}^{2}$ 以上的支流有 12 条, 包括香溪 河、大宁河、梅溪河、长滩河、磨刀溪、汤溪河、澎溪河、龙河、乌江、龙溪河、嘉陵江和綦江 ${ }^{[1]} .175 \mathrm{~m}$ 正常蓄水 水位, 从上游至下游, 水位升高 3 100 余米, 长江干流回水末端到达重庆, 回水长度约 600 余千米, 支流河口 以上形成数千米到数十千米的回水区, 干支流水面变宽、水流减缓、泥沙含量降低 ${ }^{[1-2]}$. 三峡水库蓄水不仅改 变了河流水文条件,也导致了浮游植物组成和生物量的变化 ${ }^{[3]}$.

自 $135 \mathrm{~m}$ 蓄水以来, 有关三峡水库浮游植物的研究较多,这些研究主要包括: 通过不同蓄水位蓄水过程 (蓄水前、蓄水中、蓄水后 $)^{[4-7]}$ 、蓄水完成后一段时间 ${ }^{[6,8-9]}$ 和不同时间尺度包括周变化 ${ }^{[10-11]}$ 、月变化 ${ }^{[12]}$ 、不同 季节 ${ }^{[9,13-18]}$ 或枯水期、平水期和丰水期 ${ }^{[3,12]}$ 、年际之间 ${ }^{[12-13]}$ 等,探讨干流和支流回水区浮游植物变化与水平 分布及其影响因素, 以及支流回水区春季和秋季浮游植物多样性比较 ${ }^{[19]}$ 和藻类水华研究等. 尚未见到长江 干流与支流回水区浮游植物的比较研究, 相关报道仅提及种类数、优势种类和现存量, 且研究的支流数量和 干流范围不全面 ${ }^{[3,14,16]}$. 也未见到支流未淹没区即 $175 \mathrm{~m}$ 以上自然河段的浮游植物报道. 三峡水库水生态系 统尚处于重建初期,远未达到稳定或平衡状态, 仍需持续监测较长一段时间 ${ }^{[20]}$. 2008 年 11 月开始, 三峡水 库已蓄水至 $172 \mathrm{~m}$ 水位运行, 比原来最高蓄水水位 $156 \mathrm{~m}$ 升高了 $16 \mathrm{~m}$. 为此,2010 年 4 月 (枯水期) 对三峡水 库长江干流和 26 条支流回水区与未淹没区的浮游植物多样性与水质进行了初步研究.

\section{1 材料与方法}

\section{1 研究范围与采样点设置}

长江干流为整个三峡水库回水江段, 从上游重庆至下游坝前依次设朱沱、丰收坝、寸滩、扇沱、清溪场、白 公祠、桐园、苦草沱、白帝城、培石、黄蜡石、屈原祠、银杏沱共 13 个断面 (图 1), 每个断面设左右 2 个采样点.

26 条支流自上游至下游依次为綦江、嘉陵江、五布河、御临河、龙溪河、梨香溪、渠溪河、龙河、黄金河、汝溪 河、澎溪河、汤溪河、磨刀溪、长滩河、梅溪河、草堂河、大溪河、大宁河、官渡河、抱龙河、神龙溪、青干河、吒溪河、 童庄河、香溪河、九畹溪等. 根据主河道长短, 支流未淹没区 $(175 \mathrm{~m}$ 以上主河道自然河段) 设 $2 \sim 3$ 个(上、中、下) 采 样点 (青干河只在下设 1 个采样点), 共设 65 个采样点. 根据淹没河段长短, 支流回水区 (175 m 淹没河段) 设 $2 \sim 3$ 个(上、中、下)采样点,澎溪河设 6 个采样点, 大宁河和香溪河各设 4 个采样点,共设 68 个采样点(图 1).

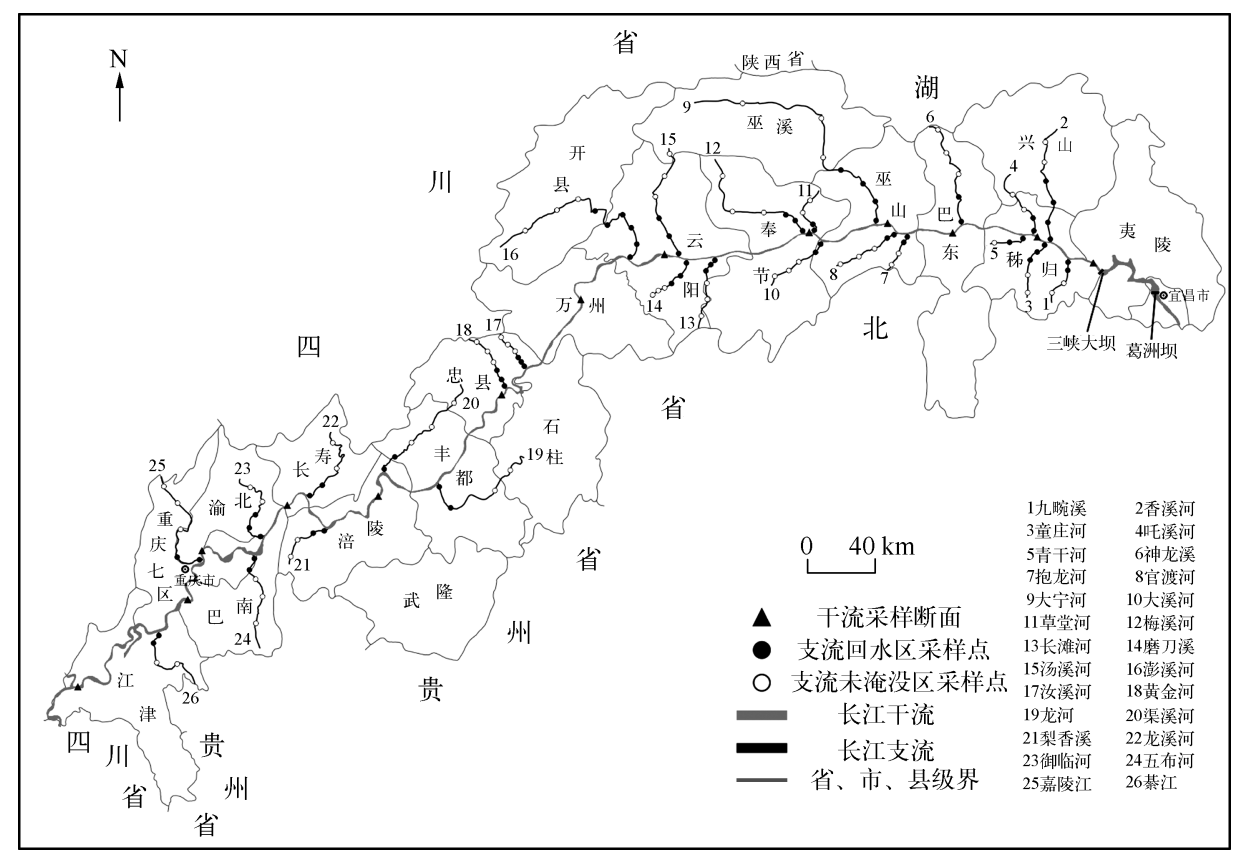

图 1 三峡水库长江干流及支流各采样断面(点) 分布

Fig. 1 Geographic distribution of sampling sites in the main stream of Yangtze River and its tributaries, 


\section{2 采样和分析方法}

2010 年 4 月在各采样点采集浮游植物定性、定量样品. 回水区和干流定性样品用 $25^{\#}$ 浮游生物网在水面 下作 “ $\infty$ ”捞取, 定量样品用 $2.5 \mathrm{~L}$ 采水器分别在 $0 、 1 、 3$ 和 $5 \mathrm{~m}$ 水深处等量取水,共取 $1 \mathrm{~L}$ 混合水样. 未淹没 区定性样品通常用 $25^{\#}$ 浮游生物网在水中将网口对水流方向捞取, 直接在水中取 $1 \mathrm{~L}$ 定量样品. 在水体面积 较大、较深、流速较缓的地方,采用干流和回水区方法采集. 所有样品现场加鲁哥氏液固定 ${ }^{[21]}$. 定性样品于光 学显微镜下 $10 \times 40$ 倍观察, 鉴定其种类 ${ }^{[22-23]}$. 定量样品在室内沉淀 $24 \mathrm{~h}$, 浓缩至 $30 \mathrm{ml}$, 取 $0.1 \mathrm{ml}$ 样品于 $0.1 \mathrm{ml}$ 计数框内进行视野法计数并鉴定种类,用细胞体积法推算生物量 ${ }^{[21-23]}$. 干流断面取左右 2 点平均值. 各采样点的 Shannon-Wiener 多样性指数 $\left(H^{\prime}\right)$ 和 Pielou 均匀性指数 $(J)$ 计算公式分别为 ${ }^{[1,24]}$ :

$$
\begin{gathered}
H^{\prime}=-\sum_{i=1}^{S}\left(n_{i} / N\right) \log _{2}\left(n_{i} / N\right) \\
J=H^{\prime} / \log _{2} S
\end{gathered}
$$

式中, $S$ 为种类数, $N$ 为同一样品中个体总数, $n_{i}$ 为第 $i$ 种个体数.

数据分析使用 SPSS 19.0 软件,用 One-way ANOVA 进行方差分析,LSD 分析法检验数据的差异性.

\section{2 结果}

\section{1 种类组成及优势种}

2. 1.1 种类组成 经调查, 干流共有浮游植物 7 门 59 属 135 种, 未淹没区共有 7 门 81 属 245 种、回水区共有 7 门 87 属 227 种, 各门种类数及所占比例见表 1. 干流、未淹没区与回水区浮游植物种类均由硅藻门、绿藻门 和蓝藻门组成, 它们占浮游植物种类的绝大部分, 达 $93.33 \% \sim 93.88 \%$, 裸藻门、甲藻门、隐藻门和金藻门种 类较少, 占6. $12 \%$ 6.66\% (表 1). 浮游植物种类组成特点与 2005 年三峡水库长江干流和香溪河回水区枯 水期 ${ }^{[3]}$ 、大宁河回水区枯水期 ${ }^{[12]}$ 和三峡水库长江干流及以下江段 ${ }^{[18]}$ 相似.

表 1 各门浮游植物种类数及所占比例

Tab. 1 Species number and proportion of each phytoplankton phylum

\begin{tabular}{cccccccccc}
\hline 水域 & 种类组成 & 蓝藻门 & 金藻门 & 硅藻门 & 隐藻门 & 甲藻门 & 裸藻门 & 绿藻门 & 合计 \\
\hline 干流 & 种类数 & 19 & 1 & 73 & 2 & 3 & 3 & 34 & 135 \\
& 未比例 $/ \%$ & 14.07 & 0.74 & 54.07 & 1.48 & 2.22 & 2.22 & 25.19 & 100 \\
未淹没区 & 种类数 & 33 & 1 & 131 & 2 & 3 & 9 & 66 & 245 \\
& 比例 $/ \%$ & 13.47 & 0.41 & 53.47 & 0.82 & 1.22 & 3.67 & 26.94 & 100 \\
\multirow{2}{*}{ 回水区 } & 种类数 & 36 & 1 & 108 & 2 & 3 & 8 & 69 & 227 \\
& 比例 $/ \%$ & 15.86 & 0.44 & 47.58 & 0.88 & 1.32 & 3.52 & 30.40 & 100 \\
\hline
\end{tabular}

2.1 .2 优势种 各采样点细胞密度占浮游植物总密度 $50 \%$ 以上的优势种类有 5 门 9 种. 干流优势种类只有 1 门 1 种, 为绿藻门多形丝藻 (Ulothrix variabilis). 未淹没区有 3 门 6 种, 包括硅藻门 3 种 (变异直链藻 (Melosira varians)、美丽星杆藻 (Asterionella formosa)、针杆藻 (Synedra sp. ))、蓝藻门 2 种 (小席藻 (Phormidium te$n u s$ )、湖泊鞘丝藻 (Lyngbya limnetica) ) 、隐藻门 1 种 (隐藻 (Cryptomonas sp. )). 回水区有 5 门 6 种, 包括蓝藻 门 2 种 (小席藻和不定腔球藻 (Coelosphaerium dubium)), 硅藻门(变异直链藻)、绿藻门(多形丝藻)、甲藻门 (拟多甲藻 (Peridiniopsis sp. )) 和隐藻门 (隐藻) 各 1 种. 其中拟多甲藻在磨刀溪、梅溪河和神农溪回水区上 游形成水华,其细胞密度分别达到 $230.0 \times 10^{4} 、 382.1 \times 10^{4}$ 和 $945.6 \times 10^{4}$ cells $/ \mathrm{L}$. 回水区出现的优势种类门 类与以往报道 ${ }^{[3,6,9,14,16,19]}$ 相同, 长江干流优势种类没有硅藻和隐藻 ${ }^{[3,14,16,18]}$.

干流有 2 个断面出现优势种类, 占调查断面的 $15.38 \%$. 未淹没区有 5 条支流 6 个地点出现优势种类， 占调查支流和采样点的 $19.23 \%$ 和 $9.23 \%$. 回水区有 11 条支流 17 个地点出现优势种类, 占调查支流和采样 点的 $42.31 \%$ 和 $25.00 \%$.

\section{2 现存量及组成}

2.2 .1 现存量 干流浮游植物细胞密度为 $2.9 \times 10^{4} \sim 14.5 \times 10^{4}$ cells/L, 白公祠最高, 屈原祠最低, 平均值为 $(7.1 \pm$ 1. 1) $\times 10^{4}$ cells $/ \mathrm{L}$; 生物量为 $0.013 \sim 0.284 \mathrm{mg} / \mathrm{L}$, 丰收坝最高, 银杏沱最低, 平均值为 $0.098 \pm 0.023 \mathrm{mg} / \mathrm{L}$ (图 2). 
密度自生物量
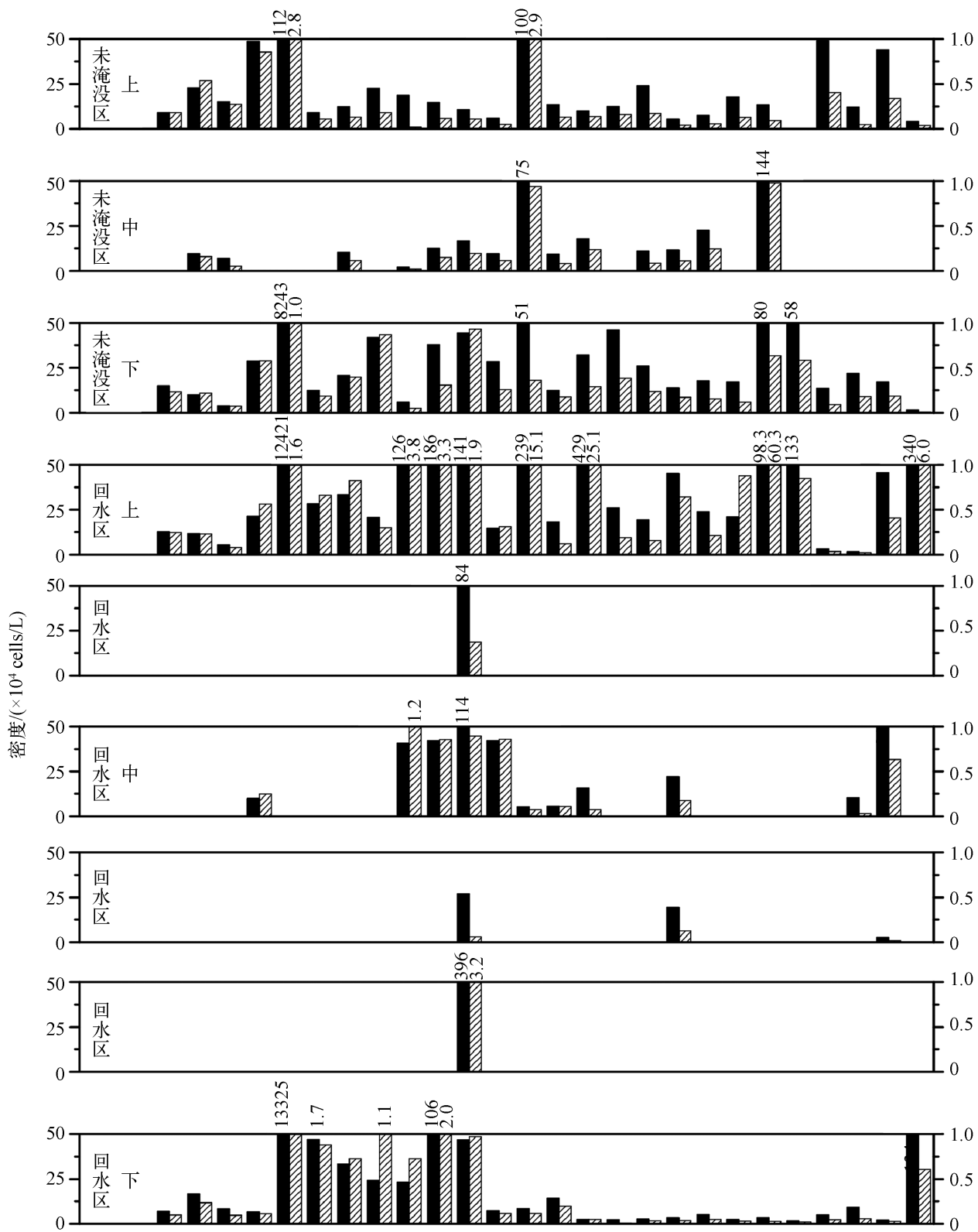

綦嘉五御龙梨渠龙黄汝澎汤磨长梅草大大官抱神青吒童香九 陵布临溪香溪金溪溪溪芀滩溪堂溪宁渡龙龙芉溪庄溪畹

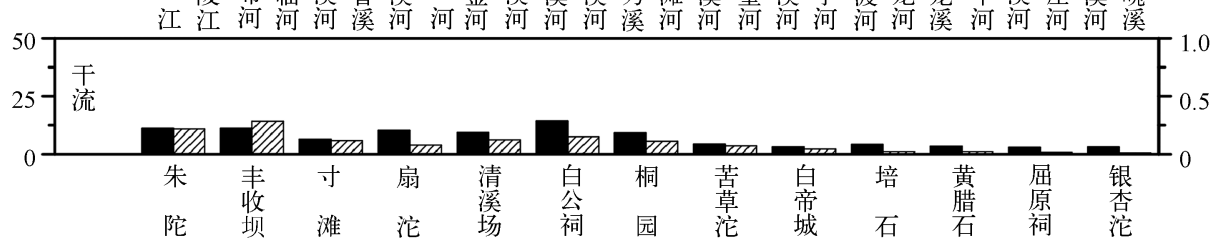

图 2 长江干流和支流浮游植物现存量的空间分布

Fig. 2 Spatial distribution of phytoplankton standing stock in the main stream and tributaries of Yangtze River 
未淹没区浮游植物细胞密度为 $1.4 \times 10^{4} \sim 8242.6 \times 10^{4} \mathrm{cells} / \mathrm{L}$, 龙溪河下最高, 九畹溪下最低, 平均值为 $(151.9 \pm 126.5) \times 10^{4}$ cells $/ \mathrm{L}$; 生物量为 $0.009 \sim 2.907 \mathrm{mg} / \mathrm{L}$, 磨刀溪上最高, 九畹溪下最低, 平均值为 $0.341 \pm$ $0.064 \mathrm{mg} / \mathrm{L}$ (图 2). 回水区浮游植物细胞密度为 $1.6 \times 10^{4} \sim 13324.8 \times 10^{4}$ cells $/ \mathrm{L}$, 龙溪河下最高, 童庄河上 最低, 平均值为 $(442.9 \pm 265.1) \times 10^{4}$ cells $/ \mathrm{L}$; 生物量为 $0.008 \sim 60.272 \mathrm{mg} / \mathrm{L}$, 神农溪上最高, 草堂河下最 低, 平均值为 $2.100 \pm 0.970 \mathrm{mg} / \mathrm{L}$ (图 2). 浮游植物密度和生物量平均值回水区最高、未淹没区其次、干流最 低, 它们之间无显著差异 $(P>0.05)$. 枯水期干流浮游植物密度低于回水区已有报道 ${ }^{[3,16]}$.

2.2 .2 现存量组成裸藻、金藻出现率和所占比例较低, 硅藻、绿藻、隐藻、蓝藻、甲藻所占比例在 3 类水域有 较大变化 (图 3). 未淹没区硅藻密度和生物量占优势, 分别占 $79.55 \% \pm 25.73 \%$ 和 79.60\% $\pm 26.38 \%$, 绿藻 $(7.25 \% 、 2.58 \%)$ 、隐藻 $(4.49 \% 、 7.88 \%)$ 、蓝藻 $(6.13 \% 、 0.76 \%)$ 、甲藻 $(2.00 \% 、 6.55 \%)$ 比例均在 $8 \%$ 以 下. 硅藻比例在未淹没区最高 (图 3), 且极显著高于干流和回水区 $(P<0.01)$.

干流硅藻密度和生物量比例 ( $49.39 \%$ 和 $49.41 \%)$ 较未淹没区极显著下降 $(P<0.01)$, 但在各门中仍最 高, 绿藻比例 $(31.24 \% 、 8.20 \%)$ 极显著 $(P<0.01)$ 或显著升高 $(P<0.05)$, 且在 3 类水域中最高 (图 3$)$, 隐 藻生物量比例 $(26.93 \%)$ 显著升高 $(P<0.05)$, 蓝藻 $(5.84 \% 、 0.05 \%)$ 和甲藻 $(1.97 \% 、 11.34 \%)$ 密度和生物 量比例、隐藻密度比例 $(11.02 \%)$ 均无显著变化 $(P>0.05)$. 浮游植物密度主要由硅藻、绿藻和隐藻贡献, 占 $91.65 \% \pm 8.17 \%$; 生物量主要由硅藻、隐藻和甲藻贡献, 占 $87.68 \% \pm 10.77 \%$.

回水区硅藻密度和生物量比例 $(27.95 \% 、 27.00 \%)$ 较干流显著 $(P<0.05)$ 或极显著 $(P<0.01)$ 下降, 密 度和生物量比例分别接近绿藻和低于隐藻水平 (图 3). 绿藻比例 (24.14\%、6.75\%) 基本保持在干流水平并 与干流无显著差异 $(P>0.05)$, 但极显著高于未淹没区 $(P<0.01)$. 同时蓝藻 $(17.57 \% 、 5.54 \%) 、$ 隐藻 $(20.20 \% 、 36.90 \%)$ 和甲藻 $(9.29 \% 、 19.69 \%)$ 比例较干流升高不显著 $(P>0.05)$, 且在 3 类水域中均最高, 它们与干流无显著差异 $(P>0.05)$, 但都极显著高于未淹没区 $(P<0.01)$. 浮游植物密度主要由硅藻、绿藻、 隐藻和蓝藻贡献, 占 $89.87 \% \pm 21.55 \%$; 生物量主要由隐藻、硅藻和甲藻贡献, 占 $83.60 \% \pm 20.81 \%$. 春季小 江回水区也呈硅藻密度减少, 绿藻、蓝藻密度增加的变化趋势 ${ }^{[9]}$.
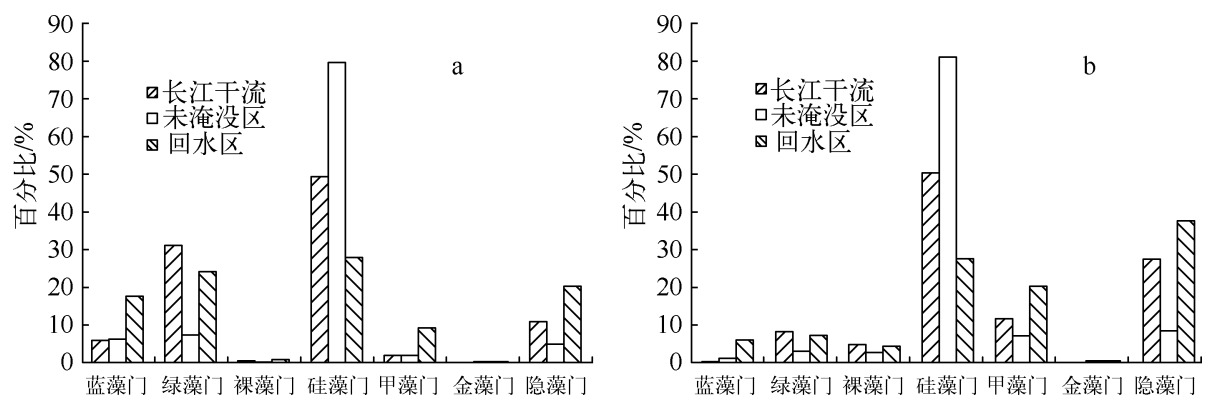

图 3 各门浮游植物密度 $(\mathrm{a})$ 和生物量 $(\mathrm{b})$ 贡献比例

Fig. 3 Percentages of density(a) and biomass(b) of each phytoplankton phylum

\section{3 多样性指数和均匀性指数及水质评价}

2.3.1 多样性指数和均匀性指数 干流各断面浮游植物多样性指数 $H^{\prime}$ 在 $2.01 \sim 3.83$ 之间, 银杏沱最低、丰 收坝最高, 平均值为 $3.12 \pm 0.14$; 均匀性指数 $J$ 在 $0.60 \sim 0.88$ 之间, 银杏沱最低、白公祠和白帝城最高, 平 均值为 $0.78 \pm 0.02$. 未淹没区 $H^{\prime}$ 在 $0.72 \sim 4.52$ 之间, 龙溪河下最低、渠溪河中最高, 平均值为 $3.67 \pm 0.09 ; J$ 在 $0.17 \sim 0.96$ 之间, 龙溪河下最低、五布河下和梨香溪上最高, 平均值为 $0.81 \pm 0.02$. 回水区 $H^{\prime}$ 在 $0.35 \sim$ 4.46 之间, 神农溪上最低、香溪河上 (高阳) 最高, 平均值为 $2.74 \pm 0.13 ; J$ 在 $0.07 \sim 0.95$ 之间, 神农溪上最 低、大溪河下和吒溪河上最高, 平均值为 $0.69 \pm 0.03$. 干流、未淹没区与回水区各点 $H^{\prime}$ 和 $J$ 值分布比例见图 4. 未淹没区 $H^{\prime}$ 和 $J$ 极显著 $(P<0.01)$ 高于回水区、 $H^{\prime}$ 显著高于干流 $(P<0.05), J$ 与干流无显著差异 $(P>$ $0.05)$. 干流与回水区之间 $H^{\prime}$ 和 $J$ 无显著差异 $(P>0.05)$.

五布河、龙溪河、梨香溪、渠溪河、龙河、澎溪河、磨刀溪、长滩河、梅溪河、草堂河、大溪河、大宁河、抱龙 河、神农溪、童庄河、吒溪河、九畹溪等 17 条支流, 回水区 $H^{\prime}$ 均低于未淹没区, 占调查支流的 $65.38 \%$, 其他 8 

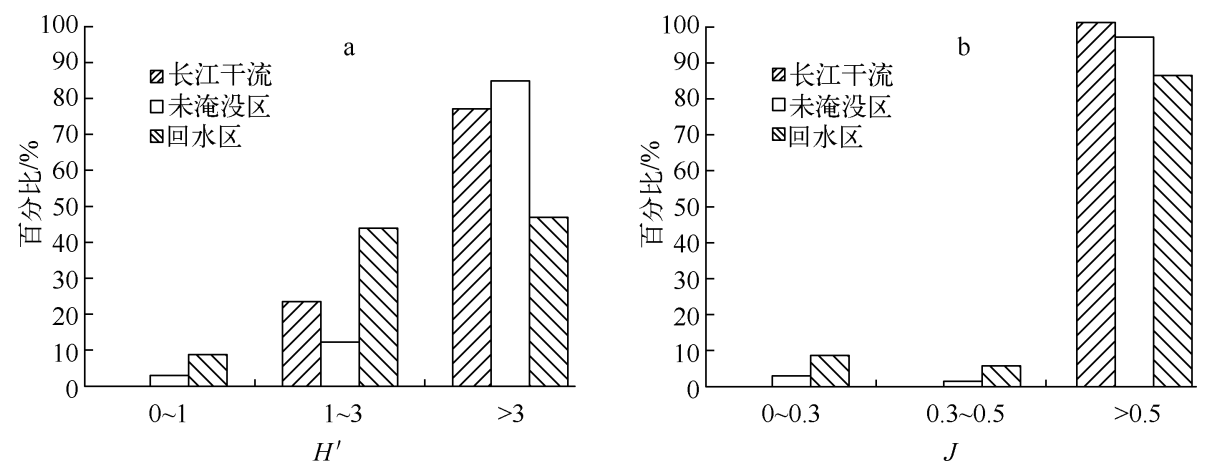

图 4 干流、未淹没区与回水区各点 $H^{\prime}(\mathrm{a})$ 和 $J(\mathrm{~b})$ 值分布比例

Fig. 4 Percentages of $H^{\prime}$ (a) and $J(\mathrm{~b})$ at each monitoring site in the main stream of Yangtze River, inundated and backwater area of tributaries

条支流 (綦江除外) 回水区和未淹没区的 $H^{\prime}$ 各有高低, 占调查支流的 $30.77 \%$. 龙溪河、梨香溪、渠溪河、澎溪 河、汤溪河、长滩河、梅溪河和九畹溪等 8 条支流, 回水区 $J$ 均低于未淹没区, 占调查支流的 $30.77 \%$, 其他 17 条支流 (綦江除外) 回水区和未淹没区的 $J$ 各有高低, 占调查支流的 $65.38 \%$. 綦江回水区 $H^{\prime}$ 和 $J$ 均高于未淹 没区,占调查支流的 $3.85 \%$.

2.3.2 水质评价按照 $H^{\prime}>3$ 为轻或无污染、 $1 \sim 3$ 为中污染、 $0 \sim 1$ 为重污染, $J$ 在 $0.5 \sim 0.8$ 为轻或无污染、 $0.3 \sim 0.5$ 为中污染、 $0 \sim 0.3$ 为重污染的评价标准 ${ }^{[19,24]}$, 干流 $76.92 \%$ 的断面 (10 个) 轻或无污染, $23.08 \%$ 的 断面 (3 个) 为中污染, 无重污染断面. 未淹没区 $84.62 \%$ 的点 (55 个) 轻或无污染, $12.31 \%$ 的点 ( 8 个) 中污 染, $3.08 \%$ 的点 (2 个) 重污染. 回水区 $47.06 \%$ 的点 (32 个) 轻或无污染, $44.12 \%$ 的点(30 个) 中污染, $8.82 \%$ 的点 (6个) 重污染 (图 4 ).

綦江、五布河、梨香溪、渠溪河、大溪河、官渡河等 6 条支流未淹没区和回水区均为轻或无污染, 占调查 支流的 $23.08 \%$. 御临河、龙河、澎溪河、汤溪河、磨刀溪、长滩河、梅溪河、草堂河、大宁河、抱龙河、吒溪河、香 溪河、九畹溪等 13 条支流未淹没区轻或无污染, 回水区出现中或重污染, 占调查支流的 $50.00 \%$. 龙溪河、黄 金河、汝溪河、青干河、神农溪和童庄河等 6 条支流未淹没区和回水区均出现中污染或重污染, 占调查支流 的 $23.08 \%$. 嘉陵江未淹没区中污染, 回水区轻或无污染, 占调查支流的 $3.84 \%$.

\section{3 讨论}

\section{1 长江干流、未淹没区与回水区浮游植物群落结构差异}

未淹没区为支流 $175 \mathrm{~m}$ 以上主河道, 不受三峡水库蓄水影响, 依然为原来自然河流状态. 干流和回水区 的水文情势发生较大变化 ${ }^{[1-2]}$, 呈现水库特点. 比较而言, 干流属河流型水库, 回水区受到干流水流的顶托, 水体交换和流速比干流慢 ${ }^{[1-2]}$, 更具有水库特点. 张远等 ${ }^{[8]}$ 根据三峡水库 $135 \mathrm{~m}$ 蓄水后的流速特征, 将干流 巴东以上江段划分为河流型水体,巴东至三峡大坝江段为过渡型水体,支流回水区为湖泊型水体.

一方面, 水文情势的变化直接影响浮游植物生存类型. Harris ${ }^{[25]}$ 认为, 水滞留时间对浮游植物种类组成 的影响取决于藻类的自身浮力, 比重较大的藻类如硅藻沉降快, 需要高的流速支持其悬浮于水中, 静水则适 合大型的和有鞭毛的藻类. Sommer ${ }^{[26]}$ 从个体生存方式, 提出藻类 $\mathrm{r}-\mathrm{k}$ 生存对策. 认为当水的扰动大于浮游 植物繁殖时间, 环境更适合于内禀增长率高的藻类, 即 $r$-策略者, 它们是先驱者, 能在扰动间隙迅速建立种 群, 这些藻类个体通常很小, 通过高繁殖率来抵御高死亡率; 而低扰动, 由于环境稳定, 则更适合于 $\mathrm{k}$-策略 者, 那些个体大、竞争力强的后来者种群达到高峰. 另一方面, 通过改变干流和回水区特别是回水区理化条 件、水文结构 (水体混合成层深度、水柱稳定性、局部流场), 间接影响浮游植物种类和生产力. 枯水期泥沙含 量降低、透明度升高, 有利于促进浮游植物的光合作用, 提高现存量. Zhang 等 $^{[12]}$ 认为枯水期大宁河回水区 透明度、TP 和溶解氧对浮游植物群落组成有明显影响. Wang 等 ${ }^{[11]}$ 指出水位波动水平明显影响香溪河回水 
区的水体混合成层深度、水柱的稳定性, 从而影响浮游植物. 朱木兰等 ${ }^{[27]}$ 分析了春季水库回水区尾端有利于 甲藻形成水华的流场.

虽然干流、未淹没区与回水区浮游植物种类组成特点基本相同 (表 1 ), 但浮游植物群落结构有明显差 异. 浮游植物优势种类, 未淹没区出现率最低 (9.23\%), 主要是硅藻, 但受到沿途城镇生活污水、农业面源污 染和筑坝的影响, 蓝藻和隐藻在某些地方也会成为优势种类. 干流优势种类出现率升高 $(15.38 \%)$, 优势种 类与未淹没区也不同, 为绿藻. 回水区优势种类出现率最高 $(25.00 \%)$, 优势种类门类最多, 除了未淹没区和 干流出现的门类外, 还有甲藻. 从浮游植物密度和生物量组成来看, 硅藻在未淹没区的比例最高, 从未淹没 区、干流到回水区, 硅藻所占比例依次极显著或显著下降. 干流和回水区绿藻、隐藻、蓝藻和甲藻所占比例较 未淹没区有不同程度升高, 绿藻在干流比例最高, 蓝藻、隐藻和甲藻在回水区比例最高, 它们在干流和回水 区之间无显著差异, 但均极显著或显著高于未淹没区. 未淹没区 $H^{\prime}$ 极显著高于回水区、显著高于干流, $J$ 极 显著高于回水区、与干流无显著差异. 干流与回水区 $H^{\prime}$ 和 $J$ 无显著差异. 因此, 未淹没区较适合硅藻生长, 干 流和回水区较适合绿藻、蓝藻、隐藻和甲藻等个体较大和具鞭毛的一些种类生长. 浮游植物群落结构未淹没 区与干流和回水区差异较大,干流和回水区差异较小.

\section{2 蓄水对长江干流和支流回水区浮游植物与水质的影响}

未淹没区与干流、回水区浮游植物群落结构差异大体反映了蓄水对干流和回水区浮游植物产生的影 响. 第一, 优势种类发生改变、出现几率增加. 未淹没区优势种类主要是硅藻, 干流为绿藻, 回水区除硅藻和 绿藻外, 还有蓝藻、甲藻和隐藻, 有些种类特别是甲藻中的拟多甲藻在一些支流回水区频繁出现水华 ${ }^{[15,19]}$. 干流和回水区优势种类出现地点比例分别升高到 $15.38 \% 、 25.00 \%$. 第二, 浮游植物现存量中, 硅藻比例下 降, 其他门类比例升高. 回水区硅藻比例下降幅度比干流更大, 干流只有绿藻和隐藻比例明显升高, 回水区 除绿藻比例保持在干流水平外, 隐藻比例继续升高, 蓝藻、甲藻比例也明显升高. 且绿藻在干流比例最高, 蓝 藻、隐藻和甲藻在回水区比例最高 (图 3 ). 第三, 浮游植物多样性指数和均匀性指数降低. 回水区 $H^{\prime}$ 和 $J$ 比 干流更低. 按照浮游植物多样性指数进行水质评价, 轻或无污染断面 (点) 的比例, 未淹没区为 $84.62 \%$ 、干流 为 $76.92 \%$ 、回水区为 $47.06 \%$ (图 4), 回水区受污染最重、干流次之、未淹没区最轻. 19 条 $(73.08 \%$ ) 支流的 回水区出现中污染或重污染, 只有 7 条 $(26.92 \%)$ 支流的未淹没区出现中污染或重污染. 因此, 蓄水对回水 区浮游植物与水质影响比长江干流更大.

水库蓄水不仅引起浮游植物组成改变, 也会引起生物量的变化 ${ }^{[3]}$. Asahi 水库建成后, 水体达到富营养 程度, 浮游植物也增加 ${ }^{[28]}$. 三峡水库蓄水后, 促进了回水区浮游植物生产, 其密度和生物量平均值比未淹没 区增加了 1.9 倍和 5.2 倍, 干流只有未淹没区的 $4.70 \%$ 和 $28.74 \%$, 但它们之间无显著差异, 蓄水对干流和 回水区浮游植物现存量的影响有待深人研究.

就不同的水文时期而言, 河流枯水期最不利水体污染物稀释、扩散、降解,水生态系统承受着最大的污 染压力, 这个时期浮游植物群落结构应该最差, 据此反映出的三峡水库蓄水对干流和回水区浮游植物影响 及水质污染也是最严重的情况.

致谢: 池仕运、胡俊、万力、冯坤、汪红军、郑志伟等同志参加部分野外采样工作,程郁春同志完成部分样品室 内处理,在此表示感谢.

\section{4 参考文献}

黄真理,李玉樑,陈永灿等.三峡水库水质预测和环境容量计算. 北京: 中国水利水电出版社,2006:6-18.

[ 2 ] 曹广晶,陈永柏.三峡库区水环境现状与对策建议. 科技导报, 2005,23(10):25-29.

[ 3 ] Zeng H, Song LR, Yu ZG et al. Distribution of phytoplankton in the Three-Gorge Reservoir during rainy and dry seasons. Science of the Total Environment, 2006, 367: 999-1009.

[4] 况琪军, 毕永红, 周广杰等. 三峡水库蓄水前后浮游植物调查及水环境初步分析. 水生生物学报, 2005, 29(4): 353-358.

[ 5 ] 韩德举, 胡菊香, 高少波等. 三峡水库 $135 \mathrm{~m}$ 蓄水过程坝前水域浮游生物变化的研究. 水利渔业, 2005, 25(5): $55-58$.

[6] 周广杰,况琪军, 胡征宇等. 香溪河浮游藻类种类演替及 “水华” 发生趋势分析. 水生生物学报, 2006,30(1):42-46. 
[ 7 ] 李 哲,王 胜, 郭劲松等. 三峡水库 $156 \mathrm{~m}$ 蓄水前后澎溪河回水区藻类多样性变化特征. 湖泊科学, 2012,24(2): 227-231.

[ 8 ] 张 远,郑丙辉, 刘鸿亮. 三峡水库蓄水后的浮游植物特征变化及影响因素. 长江流域资源与环境, 2006,15(2): 254-258.

[9] 郭劲松,陈 杰,李 哲等. $156 \mathrm{~m}$ 蓄水后三峡水库小江回水区春季浮游植物调查及多样性评价. 环境科学, 2008, 29 (10):2710-2715.

[10] Wang L, Cai QH, Zhang M et al. Longitudinal patterns of phytoplankton distribution in a tributary bay under reservoir operation. Quaternary International, 2011, 244 :280-288.

[11] Wang L, Cai QH, Xu YY et al. Weekly dynamics of phytoplankton functional groups under high water level fluctuations in a subtropical reservoir-bay. Aquatic Ecology, 2011,45(2):197-212.

[12] Zhang JL, Zheng BH, Liu LS et al. Seasonal variation of phytoplankton in the DaNing River and its relationships with environmental factors after impounding of the Three Gorges Reservoir: A four-year study. Procedia Environmental Sciences, 2010,2 : 1479-1490.

[13] 况琪军,胡征宇, 周广杰等. 香溪河流域浮游植物调查与水质评价. 武汉植物学研究, 2004,22(6):507-513.

[14] 陈 勇,段辛斌, 刘绍平等. 三峡水库三期蓄水后浮游植物群落结构特征初步研究. 淡水渔业,2009,39(1):10-15.

[15] 朱爱民, 吴广兵, 梁银铨等. $156 \mathrm{~m}$ 蓄水后三峡水库支流童庄河河口段浮游植物群落的时空动态. 水生态学杂志, 2009,2(2) : 101-106.

[16] 胡建林,刘国祥,蔡庆华等.三峡库区重庆段主要支流春季浮游植物调查. 水生生物学报,2006,30(1):116-119.

[17] Yang M, Bi YH, Hu JL et al. Seasonal variation in functional phytoplankton groups in Xiangxi Bay, Three Gorges Reservoir. Chinese Journal of Oceanology and Limnology, 2011, 29(5) : 1057-1064.

[18 ] Zeng H, Song LR, Yu ZG et al. Post-impoundment biomass and composition of phytoplankton in the Yangtze River. Internat Rev Hydrobiol, 2007, 92 (3) :267-280.

[19］周广杰,况琪军, 胡征宇等. 三峡库区四条支流藻类多样性评价及 “水华” 防治. 中国环境科学, 2006, 26 (3): 337-341.

[20] 胡征宇,蔡庆华. 三峡水库蓄水前后水生态系统动态的初步研究. 水生生物学报, 2006,30(1):1-6.

[21] 章宗涉,黄祥飞. 淡水浮游生物研究方法. 北京:科学出版社,1991:333-344.

[22] 胡鸿钧,李尧英,魏印心等. 中国淡水藻类. 上海:上海科学技术出版社, 1980:1-492.

[23] 胡鸿钧,魏印心. 中国淡水藻类——系统、分类及生态. 北京:科学出版社, 2006:1-915.

[24] 沈暳芬,章宗涉,龚循矩等. 微型生物监测新技术. 北京: 中国建筑工业出版社, 1990:136.

[25] Harris GP. Temporal and spatial scales in phytoplankton ecology: Mechanisms, methods, and management. Can J Fish Aqua Sci, $1980,37: 877-900$.

[26] Sommer U. The role of r-and k-selection in the succession of phytoplankton in Lake Constance. Acta Ecologia, 1981, 2:327342.

[27] 朱木兰,陈飞勇,金 峰等. 水库甲藻水华与防治效果数值模拟. 人民长江, 2007,38(11): 157-159.

[28 ] Kawara O, Yura E, Fujii S et al. A study on the role of hydraulic retention time in eutrophication of the Asahi River Dam Reservoir. Water Sci Technol, 1998,37 (2) :245-252. 